\title{
農薬の分子設計とコンピューターケミストリー Molecular Design of Pesticides and Computational Chemistry
}

\author{
Phytoene desaturase 阻害による白化型除草剤の三次元構造活性相関 ……………………......番場伸一 \\ 殺菌剂メトコナゾールの分子設計と三次元定量的構造活性相関解析 (3D-QSAR) \\ 中馬 寛 (330) \\ ネオニコチノイド系殺虫剤の分子 similarity と構造活性相関 \\ 中山 章 (336)
}

昆虫と哺乳類の GABA 受容体におけるアンタゴニスト結合部位の構造：3D-QSAR からの

アプローチ

赤松美紀

オーガナイザー：赤松美紀（京都大），尾添嘉久（島根大）

医農薬のデザインにおいて，医農薬であるリガンドとそ の受容体との相互作用に関する知識を得ることはきわめて 重要である。この知識を得るには，大きく分けて 2 通りの 方法が存在する。すなわち，リガンド側から知識を得る方 法と受容体側から得る方法である．前者の方法に関して， 誰でも利用できるソフトウェアが多数市販されている。と りわけ，最近では，コンピューター技術の急速な発展に伴 い，分子の三次元構造が計算機上で比較的容易に得られる ようになったことから，薬物の三次元構造と活性との間の 関係を定量的に解析するソフトウェアがよく使用されてい る。また，後者に関しては，X 線結晶構造解析の方法の進 歩から，近年，多数のタンパク質の立体構造が解明されて きており，受容体タンパク質から得られた情報を元に新規 の高活性化合物をデザインする試みも行われている。しか しながら，一般的には受容体タンパク質の立体構造が未知 である場合が多く，膜タンパク質の場合には X 線結晶構造 解析も困難であるというのが現状である，従って，ほとん どの場合には，リガンド側から得られた受容体構造に基づ き，医農薬をデザインすることとなる.

医薬に関しては，分子モデリングを行って高活性化合物 をデザインする試みが盛んであるが，農薬に関してはまだ まだ成功例が少く，コンピューターがうまく利用されてい
るとは言い難い。本シンポジウムでは，コンピューターケ ミストリーを利用して農薬の分子設計を行った事例あるい はその可能性を示した事例を，4名の方々に話していただ いた，残念ながら，三井化学の番場氏には，御都合により 原稿を書いていただくことができなかったが，既存の phytoene desaturase 阻害型除草剂の重ね合わせから新規の 骨格を有する化合物をデザインし, Hansch-Fujita 法および CoMFA 法による定量的構造活性相関によりその構造を最 適化したという御講演であった。

いずれも非常に興味深い御講演であり，農薬のデザイン の立場から見て，化合物を立体的に捉えることの重要性が よく理解していただけたと思う。ただ，一言申し述べたい のは，研究者が，市販のソフトウェアを用いて気軽に 3DQSAR 解析を行えるような時代になりつつあるが，得られ た相関式および受容体のイメージ図を鵜吞みにしてはなら ないということである，研究者が，自らの目で結果を確認 し自らの頭でその意味を考えるならば, 3D-QSAR は, 医農 薬のデザインにおいてこれからも有効な手法となることで あろう。

最後に，この場を打借りして，活発な討論を誘発し，シ ンポジウムに対し多大なご協力をいただいた座長の方々に 御礼申し上げたい。 